Fakultas Hukum Universitas Lancang Kuning, Jalan Yos Sudarso KM 8 Rumbai Pekanbaru,

Riau,Kode Pos 28266. Telp: (+62761)-51877

E-mail: jurnal.respublica@ac.id

Website: https://journal.unilak.ac.id/index.php/Respublica

\title{
Implementasi Sanksi Pidana Dalam Perlindungan Terbatas Jenis Ikan Terubuk Di
}

\section{Provinsi Riau.}

\author{
Tengku Arif Hidayat ${ }^{\mathrm{a}}$, Maria Maya Lestari ${ }^{\mathrm{b}}$, Ledy Diana ${ }^{\mathrm{c}}$ \\ ${ }^{a}$ Fakultas Hukum, Universitas Riau, Indonesia, Email: tengku.arif@lecturer.unri.ac.id \\ ${ }^{\mathrm{b}}$ Fakultas Hukum, Universitas Riau, Indonesia, Email: maria.maya@lecturer.unri.ac.id \\ ${ }^{\mathrm{c}}$ Fakultas Hukum, Universitas Riau, Indonesia, Email: ledy.diana@lecturer.unri.ac.id
}

\section{Article Info \\ Keywords: \\ Criminal \\ Protection \\ Terubuk}

Article History:

Received : 01-04-2021

Revised : 20-05-2021

Accepted : 10-08-2021

Published : 28-11-2021

\section{Informasi Artikel}

\section{Histori Artikel:}

Diterima : 01-04-2021

Direvisi : 20-05-2021

Disetujui : 10-08-2021

Diterbitkan : 28-11-2021

\section{Kata Kunci:}

Pidana

Perlindungan

\begin{abstract}
implementation of criminal sanctions in the limited protection of the terubuk fish species in the province of Riau. The methodology uses sociological methods. The process of implementing the Decree of the Minister of Maritime Affairs and Fisheries in Riau Province is still only in the form of giving verbal and written reprimands accompanied by a continuous socialization process by attaching stickers to fishing boats and distributing brochures about the prohibition of fishing terubuk in certain places and at certain times. certain. It is hoped that from the process of giving warnings and socializing on an ongoing basis, the objectives of the Decree of the Minister of Marine Affairs and Fisheries in the form of protection of terubuk fish can be achieved.

Selengkapnya tentang implementation.
\end{abstract}

\begin{abstract}
Abstrak
implementasi sanksi pidana dalam perlindungan terbatas jenis ikan terubuk di provinsi riau. Metodologi menggunakan metode sosiologis. Proses pelaksanaan Keputusan Menteri Kelautan dan Perikanan di provinsi riau masih hanya berupa pemberian teguran baik secara lisan maupun tertulis disertai dengan dilakukannnya proses sosialisasi secara berkelanjutan dengan melakukan penempelan stiker kepada kapal-kapal nelayan dan pembagian brosur tentang pelarangan pnagkapan ikan terubuk pada tempat tertentu dan pada waktu tertentu. Diharapkan dari adanya proses pemberian teguran dan sosialisasi secara berkelanjutan dapat dicapainya tujuan dari Keputusan Menteri Kelautan dan Perikanan berupa perlindungan ikan terubuk.
\end{abstract}




\section{PENDAHULUAN}

Mewujudkan pengelolaan sumber daya ikan dan lingkungannya secara berkelanjutan dapat dilakukan dengan cara penetapan kawasan konservasi perairan agar dapat dikelola dan dilindungi dengan lebih tersistematis berdasarkan zonasinya. ${ }^{1}$ Dengan adanya penetapan kawasan konservasi diharapkan dapat mencapai sasaran pemanfaatan berkelanjutan sumber daya ikan dan ekosistemnya sehingga dapat menjamin ketersediaan dan peningkatan kualitas nilai untuk meningkatkan kesejahteraan masyarakat disekitar kawasan konservasi perairan. ${ }^{2}$

Di provinsi Riau, konservasi perikanan yang telah mendapat ketetapan dan perlindungan hukum adalah Ikan Terubuk berdasarkan Keputusan Menteri Kelautan dan Perikanan Nomor KEP. 59/MEN/2011 tentang Penetapan Status Perlindungan Terbatas Jenis Ikan Terubuk (TENUALOSA MACRURA). Habitat penyebaran ikan terubuk berada di daerah estuaria pada perairan Kabupaten Bengkalis, Kabupaten Kepulauan Meranti, dan Kabupaten Siak, Provinsi Riau.

Perlindungan jenis Ikan Terubuk (Tenualosa macrura) di wilayah Propinsi Riau diatur dengan Kepmen KP No. KEP.59/MEN/2011, yaitu dengan status perlindungan terbatas, untuk lokasi tertentu yaitu sepanjang jalur ruaya pemijahan di perairan Kabupaten Bengkalis, Kabupaten Kepulauan Meranti, dan Kabupaten Siakyang (kawasan perairan Selat Bengkalis hingga ke muara Sungai Siak dan Sungai Apit), dan untuk periode waktu penangkapan tertentu yaitu: ${ }^{3}$

- larangan penangkapan jenis Ikan Terubuk (Tenualosa macrura) saat pemijahan pada bulan terang di bulan Agustus sampai dengan bulan November setiap tanggal 13, 14, 15, dan 16 kalender Hijriyah; dan

- larangan penangkapan jenis Ikan Terubuk (Tenualosa macrura) saat pemijahan pada bulan gelap di bulan Agustus sampai dengan bulan November setiap tanggal 28, 29, 30, dan 1 kalender Hijriyah.

\footnotetext{
${ }^{1}$ Permen KKP Nomor PER.02/MEN/2009 tentang Tata Cara Penetapan Kawasan Konservasi Perairan, pasal 1 ayat 1.

${ }^{2}$ Ibid, pasal 2 ayat 2.

${ }^{3} \mathrm{KKP}$, diunduh dari web resmi KKP https://kkp.go.id/djprl/bpsplpadang/page/316-terubuk, pada 1 Maret 2021.
} 
Lokasi Populasi Ikan Terubuk

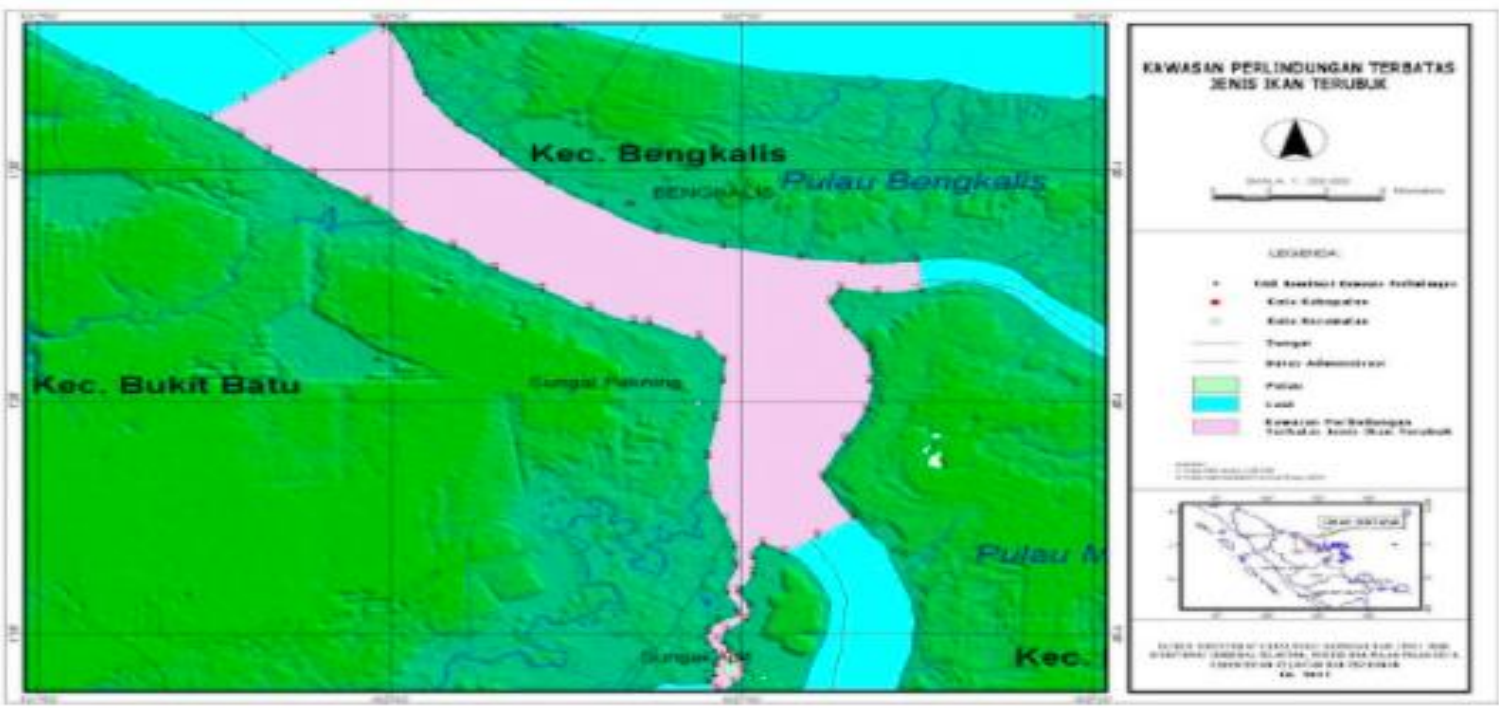

Sumber : Kepmen KP No. KEP.59/MEN/2011

Apabila dibandingkan dengan periode tahun 1960-an, saat ini populasi Ikan Terubuk sudah jauh mengalami penurunan dan sudah semakin sulit ditangkap. Penurunan populasi ini disebabkan karena penangkapan Ikan terubuk pada saat melakukan proses memijah untuk diambil telurnya dan diperjualbelikan dengan harga yang tinggi. Selain kegiatan penangkapan ikan, pencemaran yang terjadi di sepanjang Daerah Aliran Sungai (seperti Sungai Siak dan bermuara di Selat Bengkalis) juga turut memberikan andil yang besar bagi kelestarian Ikan Terubuk. $^{4}$

Penurunan hasil tangkapan yang sangat tajam ini dapat dianggap sebagai pencerminan penurunan populasi ikan terubuk, namun sejak kapan terjadinya belum diketahui secara pasti. Satu hal yang tidak dapat dipungkiri adalah, yang bernilai ekonomis tinggi pada hewan ini

4 Adi Tiaraputri dan Ledi Diana, Peran Serta Masyarakat Dalam Pengelolaan Sumber Daya Ikan di Kabupaten Bengkalis Dalam Perspektif Hukum Laut Nasional, Riau Law Journal, (Vol. 2, No. 1), 2018. Hal. 134. 
bukan pada ikannya itu sendiri, namun lebih pada telurnya yang terkenal sangat lezat. Jelas perburuan terhadap telur ikan ini menambah drastis laju penurunan populasi ikan tersebut.

Berdasarakan keterangan masyarakat sekitar Bengkalis dan juga pedagang di Pasar Bengkalis, saat ini jumlah ikan terubuk sudah tidak sebanyak dulu. ${ }^{5}$ Bahkan berkurangnya populasi dan ketersediaan ikan terubuk tidak hanya akibat penangkapan yang berlebih namun juga akibat kondisi perairan Selat Bengkalis yang sudah mengalami degradasi kualitas ekosistem karena tingkat pencemaran yang terjadi.

Berdasarkan latar belakang tersebut maka adapun rumusan masalah yang akan diangkat dalam peneltian ini adalah:

1. Bagaimana implementasi sanksi pidana dalam perlindungan terbatas jenis ikan terubuk di provinsi riau?

Metodologi yang akan digunakan dalam penelitian ini adalah dengan menggunakan metode quantitative untuk menemukan bukti-bukti empiris ${ }^{6}$ dan wawancara dengan pihakpihak terkait, seperti Pengawas Sumber Daya Kelautan dan Perikanan Kementerian Kelautan Dan Perikanan Satwas Rohil, Balai Pengelolaan Sumber Daya Pesisir dan Laut Padang Wilayah Kerja Pekanbaru, Dinas Kelautan dan Perikanan Provinsi Riau. Selain itu penelitian ini juga akan didukung oleh data sekunder dengan hasil-hasil riset dan jurnal terdahulu yang telah meneliti mengenai ikan terubuk dan populasinya.

Penelitian akan dilakukan di Kabupaten Bengkalis dan Kabupaten Meranti, guna mencari data pendukung untuk menjawab pertanyaan penelitian. Populasi dalam penelitian ini adalah nelayan tradisional yang menangkap Ikan di Kabupaten Bengkalis dan Kabupaten Meranti. Teknik pengambilan sample dilakukan dengan cara purposive sampling, dengan penetapan kriteria sampling nelayan yang menangkap ikan terubuk di zona perlindungan terubuk.

Penelitian ini akan menjadikan nelayan di kabupaten Bengkalis sebagai populasi dan sample dalam penelitian ini, sebagaimana terdapat dalam table berikut:

\footnotetext{
${ }^{5}$ Data wawancara secara acak kepada masyarakat Bengkalis dan Ketua LAM Adat Bengkalis, tahun 2020.

${ }^{6}$ Creswell, J. W., Research design: Qualitative and quantitative approaches, Thousand Oaks, CA: SAGE Publications. (1994).
} 


\begin{tabular}{|l|l|l|l|}
\hline No & Kabupaten & Populasi Nelayan & Sample (20\%) \\
\hline 1. & Bengkalis & 941 & 188 \\
\hline 2. & Meranti & 260 & 52 \\
\hline
\end{tabular}

Sumber data : KKP, 2021

Data yang akan digunakan dalam penelitian ini adalah data primer dengan melakukan wawancara, serta didukung oleh data sekunder berupa jurnal dan buku-buku yang berkenaan dengan lingkungan dan ikan terubuk.

\section{ANALISIS DAN PEMBAHASAN}

Dalam setiap penelitian harus disertai dengan pemikiran-pemikiran teoritis. Teori adalah untuk menerangkan dan menjelaskan gejala spesifik untuk proses tertentu terjadi. ${ }^{7}$ Kerangka teori merupakan landasan dari teori atau dukungan teori dalam membangun atau memperkuat kebenaran dari permasalhan yang dianalisis. ${ }^{8}$ Sehingga teori digunakan sebagai pisau analisi untuk membedah suatu permasalahan hukum yang terjadi masyarakat.

Dalam peraturan perundangan-undangan tentang kelautan terutama mengangkat bidang perikanan kategori tindak pidana dibedakan menjadi "kejahatan" dan "pelanggaran". Namun, baik dalam tindak pidana kejahatan maupun pelanggaran tindak pelanggaran tidak terdapat istilah Illegal Fishing. Istilah ini terdapat dalam penjelasan Undang-undang Nomor 45 tahun 2009 Tentang Perikanan.

Istilah illegal fishing populer dipakai oleh aparat penegak hukum dan instansi terkait untuk menyebut tindak pidana perikanan, seperti dalam acara laporan singkat rapat kerja KOMISI III DPR RI,yang menyebut frasa Illegal fishing. Ilegal fishing berasal dari kata illegal yang berarti tidak sah atau tidak resmi, dan fishing merupakan kata benda yang berarti perikanan. Dari kata fish dalam bahasa inggris yang berarti ikan, mengambil, merogoh, dan mengail,atau memancing. ${ }^{9}$ Merujuk pada pengertian illegal pada pengertian illegal fishing,

\footnotetext{
${ }^{7}$ Soerjono Soekanto, 1986, Pengantar Penelitian Hukum, UI Press, Jakarta, hlm.123.

${ }^{8}$ M.Solly Lubis, 1994, Filsafat Ilmu dan Peneltian, Mandar MAJU, Bandung, hlm.80.

${ }^{9}$ Nunung Mahmudah, 2015, Illegal Fhising, Sinar Grafika, Jakarta, hlm. 2015.
} 
secara umum dapat di identifikasi menjadi empat golongan yang merupakan illegal fishing yang umum terjadi di Indonesia, yaitu:

1. Penangkapan ikan tanpa izin

2. Penangkapan ikan dengan menggunakan izin palsu

3. Penangkapan ikan dengan menggunakan alat tangkap terlarang

4. Penangkapan ikan dengan jenis (spesies) yang tidak sesuai dengan izin. ${ }^{10}$

Kasus penangkapan ikan secara illegal yang terdapat diwilayah suatu negara dapat menggangu suistainable fisheries mengintai penangkapan illegal sering kali dilakukan tidak sesuai dengan ketentuan-ketentuan yang ada. Indonesia sangat memberikan perhatian yang serius dalam melindungi kekayaaan sumber daya alam nya dibidang perikanan dengan menerbitkan peraturan-peraturan yang di harapkan dapat memberikan perlindungan kepada spesies-spesies tertentu yang dianggap terancam keberadaannya dikarenkan tidak di terapkannya suistainable fisheries.

Salah satu sumber daya dibidang perikanan yang dilindungi keberadaanya adalah ikan terubuk. Ikan terubuk sendiri dalam bahasa latin dikenal dengan Tenualosa sp merupakan ikan tropika penghuni perairan Estuaria dan menyukai wilayah perairan payau. Terdapat 5 jenis ikan terubuk yang ada di dunia, yaitu:

1. Tenualosa Macrura (Diperairan bengkalis, Indonesia)

2. Tenualosa Ilisha (Diperairan labuhan batu, Indonesia)

3. Tenualosa Toli (Diperairan Malaysia)

4. Tenualosa Reevisi (Diperairan China)

5. Tenualosa Thibaudeaui (Diperairan Mekong)

Ikan terubuk mempunyai sifat hermafrodit proandiri yang menjalani siklus hidup dalam waktu kurang dari 2 tahun atau 18 bulan. Kehidupan pertama ikan terubuk dilalui sebagai jantan atau disebut pias dan kehidupan kedua dilalui sebagai betina atau disebut terubuk. Dalam upaya memberikan perlindungan terhadap ikan terubuk pemerintah telah membuat beberapa peraturan dalam upaya melindungi populasi ikan terubuk, diantaramya yaitu:

1. Undang-Undang Republik Indonesia Nomor 31 Tahun 2004 tentang perikanan sebagaimana telah diubah dengan Undang-Undang Nomor 45 tahun 2009

\footnotetext{
${ }^{10}$ Ibid., hlm 81.
} 
2. Keputusan Menteri Kelautan dan Perikanan Nomor 43/KEPMEN-KP/2016 tentang Penetapan Status Perlindungan Terbatas Ikan Terubuk (Tenualosha Ilisha)

3. Keputusan Menteri Kelautan dan Perikanan Nomor KEP.59/MEN/2011 tentang Penetapan Status Perlindungan Terbatas Ikan Terubuk (Tenualosha Macrura)

4. Peraturan Menteri Kelautan dan Perikanan Nomor 17/PERMEN-KP/2014 tentang Pelaksanaan Tugas Pengawas Perikanan

5. Peraturan Gubernur Riau Nomor 78 Tahun 2012 tentang Suaka Perikanan Ikan Terubuk di Provinsi Riau

Adapun perlindungan jenis ikan terubuk diwilayah provinsi riau diatur secara spesifik dengan Keputusan Menteri Kelautan dan Perikanan Nomor KEP.59/MEN/2011 tentang Penetapan Status Perlindungan Terbatas Ikan Terubuk (Tenualosha Macrura) Keputusan Menteri Kelautan dan Perikanan Nomor KEP.59/MEN/2011 tentang Penetapan Status Perlindungan Terbatas Ikan Terubuk (Tenualosha Macrura). Dalam keputusan menteri ini perlindungan ikan terubuk diberikan pada lokasi tertentu yaitu sepanjang jalur ruaya pemijahan di perairan Kabupaten Bengkalis, Kabupaten Kepulauan Meranti dan Kabupaten Siak yang secara rinci terdapat di kawasan perairan selat bengkalis hingga ke muara sungai siak dan sungai apit dalam periode waktu penangkapan tertentu, yaitu:

1. Larangan penangkapan jenis Ikan Terubuk saat pemijahan pada bulan terang di bulan agustus sampai dengan bulan november setiap tanggal 13,14,15 dan 16 Hijryah

2. Larangan penangkapan jenis ikan terubuk saat pemijahan pada bulan gelap di bulan agustus sampai dengan bulan november setiap tanggal 28,29,30 dan 1 kalender hijriyah

Populasi ikan terubuk pada periode tahun 1960 an sangat berlimpah namun hal ini berbanding terbalik jika dibandingkan dengan periode 1970 an yang semain berkurang bahkan terus menurun pada periode 1980 an. Penurunan populasi ikan terubuk ini tidak hanya disebabkan oleh aktivitas penangkapan semata, namun juga dipengaruhi oleh penurunan kwalitas perairan, terutama perairan disekitar lokasi pemijahan utama ikan terubuk di perairan bengkalis.

Dalam rangka menindaklajuti peraturan dalam perlindungan sumber daya perikanan di provinsi riau, terdapat beberapa lembaga yang berperan dalam fungsi pengawasan dan 
penegakan peraturan dalam hal perlindungan ikan terubuk diantaranya yaitu Direktorat Pengawasan Sumber Daya Kelautan dan Perikanan Kementerian Kelautan Dan Perikanan, Balai Pengelolaan Sumber Daya Pesisir dan Laut Padang Wilayah Kerja Pekanbaru, Dinas Kelautan dan Perikanan Provinsi Riau, Dinas Kelautan dan Perikanan Kabupaten Bengkalis, serta Dinas Kelautan dan Perikanan Kabupaten Siak.

Balai Pengelolaan Sumber Daya Pesisir dan Laut Padang Wilayah Kerja Pekanbaru bertugas melakukan monitoring di 3 lokasi yaitu di kecamatan bukit batu, kecamatan bengkalis, kecamatan sungai apit dengan menenempatkan enumerator yang bertugas mencatat sampling jumlah ikan dan panjang ikan yang ditangkap oleh nelayan sejak 2016. Dari hasil monitoring didapatkan hasil yang fluktuatif dengan melakukan pendekatan sponing potential ratio, dengan kseimpulan ikan terubuk masih mengalami over eksploitasi walaupun ada sedikit perbaikan yang menunjukkan penurunan angka over eksploitasinya. ${ }^{11}$

Jika dilihat kepatuhan nelayan dari kegiatan pengawasan yang dilakukan dengan melibatkan beberapa intansi seperti Dinas Kelautan dan Perikanan Provinsi Riau dan Pengawasan Sumber Daya Kelautan dan Perikanan satwas rohil nelayan sudah mengetahui adanya larangan dan perlindungan terhadap ikan terubuk di selat bengkalis, namun sebagian besar nelayan tersebut memberikan alasan bahwa ikan terubuk yang mereka tangkap terjadi dikarenakan faktor ketidaksengajaan pada saat menangkap ikan lainnya seperti ikan lomek dan ikan biang. Ketika ikan terubuk tersebut tertangkap nelayan beralasan tidak dilakukan release dikarenakan dikhawatirkan ikan tersebut tidak dapat bertahan hidup sebagaimana mestinya atau ada beberapa kasus ikan terubuk tersebut menjadi mati ketika terjadinya proses penangkapannya. $^{12}$

Kebanyakan nelayan yang tertangkap ketika melakukan penangkapan ikan terubuk merupakan nelayan yang masuk kedalam kategori nelayan kecil sehingga tindakan yang dilakukan ketika ditemukannya kasus tersebut hanya berupa himbauan dan pemberian surat pemberitahuan dan pembuatan surat pernyataan yang dibuat oleh nelayan yang bersangkutan atau dengan kata lain masih dilakukan proses penegakan hukum persuasif dan tidak menggunakan kekuatan atau aksi represif dalam penegakan hukumnya. ${ }^{13}$

\footnotetext{
${ }^{11}$ Wawancara dengan Ibu Pratmi Balai Pengelolaan Sumber Daya Pesisir dan Laut Padang Wilayah Kerja Pekanbaru

${ }^{12}$ Ibid

${ }^{13}$ Ibid
} 
Dari keterangan yang dilakukan oleh nelayan tersebut mereka menghendaki adanya insentif ataupun pemberan mata pencaharian alternatif yang dapat mereka laksanakan selama masa larangan penangkapan ikan terubuk yang sudah pernah dilakukan di labuhan batu oleh Kementerian Kelautan dan Perikanan Sumatera Utara dengan pemberian jaring tangkap gulama yang ditujukan agar nelayan-nelayan di labuhan batu melakukan penangkapan terhadap ikan gulama selama masa larangan penangkapan ikan terubuk, namun dari hasil evaluasi kegiatan ini tidak memberikan dampak yang signifikan dikarenakan nelayan masih juga mengincar ikan terubuk dan telur ikan terubuk yang memiliki nilai ekonomis yang tinggi. ${ }^{14}$

Selama ini pemberian insentif bisa diberikan kepada pegiat-pegiat konservasi jenisjenis yang dilindungi, namun di daerah wilayah konservasi ikan terubuk sampai saat ini masih belum ada kelompok yang masuk intens dalam konservasi ikan terubuk yang menjadi hambatan tersendiri dalam pemberian insentif tersebut kepada masyarakat. ${ }^{15}$

Pengawas Sumber Daya Kelautan dan Perikanan Satwas Rohil memiliki wilayah kerja di 12 kabupaten kota yang ada di provinsi riau. Proses pengawasan terhadap ikan terubuk telah dilakukan Pengawas Sumber Daya Kelautan dan Perikanan Rohil sejak tahun 2016. Pada tahun 2018 dilakukan pegawasan terhadap penangkapan ikan trubuk di dua tempat yaitu kabupaten kepulauan meranti dan kabupaten bengkalis bersama dengan Direktorat Pengawasan Sumber Daya Kelautan dan Perikanan Kementerian Kelautan Dan Perikanan, Balai Pengelolaan Sumber Daya Pesisir dan Laut Padang Wilayah Kerja Pekanbaru, Dinas Kelautan dan Perikanan Provinsi Riau, Dinas Kelautan dan Perikanan Kabupaten Bengkalis, serta Dinas Kelautan dan Perikanan Kabupaten Siak, pada saat dilakukan kegiatan patroli bersama ini dilakukan pengawasan dan pemeriksaan kepada 11 kapal yang diantara nya ditemukan 4 kapal yang terdapat ikan terubuk, namun pada saat ditemukan adanya ikan terubuk yang di tangkap hanya diberikan peringatan secara lisa serta sosialisasi berupa stiker kepada nelayan dari ke 4 kapal yang ditemukannya ikan terubuk tersebut. ${ }^{16}$

Proses perlindungan ikan terubuk dengan adanya Keputusan Menteri Kelautan dan Perikanan merupakan sebuah wujud dari kehadiran dan keseriusan pemerintah baik dalam hal ini pemerintah pusat maupun daerah dalam rangka untuk melindungi keberadaan dari ikan terubuk. Jika di tinjau dari aspek implementasi sanksi pidana dalam perlindungan terbatas

\footnotetext{
${ }^{14} \mathrm{Ibid}$

${ }^{15} \mathrm{Ibid}$

${ }^{16}$ Wawancara dengan Bapak Zulkadrihani Pengawasan Sumber Daya Kelautan dan Perikanan Satwas Rohil
} 
jenis ikan terubuk di provinsi riau pada saat ini belum di laksanakan oleh jajaran terkait dikarenakan masih menggunakan pendekatan-pendekatan persuasif kepada nelayan yang masih melakukan penangkapan ikan terubuk dikarenakan nelayan-nelayan yang melakukan penangkapan ikan terubuk masih masuk dalam kategori nelayan kecil yang memiliki kapal yang tidak lebih dari 5 GT.

Proses pelaksanaan Keputusan Menteri Kelautan dan Perikanan di provinsi riau masih hanya berupa pemberian teguran baik secara lisan maupun tertulis disertai dengan dilakukannnya proses sosialisasi secara berkelanjutan dengan melakukan penempelan stiker kepada kapal-kapal nelayan dan pembagian brosur tentang pelarangan pnagkapan ikan terubuk pada tempat tertentu dan pada waktu tertentu. Diharapkan dari adanya proses pemberian teguran dan sosialisasi secara berkelanjutan dapat dicapainya tujuan dari Keputusan Menteri Kelautan dan Perikanan berupa perlindungan ikan terubuk.

Pada september tahun 2019 dilakukan pengawasan pada waktu larangan penangkapan ikan terubuk dan ditemukan adanya 5 kapal yang kedapatan melakukan penangkapan terhadap ikan terubuk walaupun pada saat dilakukannya penangkapan ditemukan juga jenis ikan lainnya berupa ikan biang, ikan lomek dan ikan lainnya. Ketika ditemukannya ikan terubuk dalam 5 kapal yann ditangkap tersebut juga diberikan teguran secara lisan serta dilakukan sosialisasi tentang ikan terubuk berupa stiker dan brosur tentang larangan penangkapan ikan terubuk di tempa-tempat tertentu dan waktu-waktu tertentu. ${ }^{17}$

Alasan yang selalu ditemukan dan disampaikan oleh nelayan mereka melakukan penangkapan ikan terubuk dikarenakan nilai ekonomis dari ikan terubuk tersebut, namun jika dilihat dari aspek pengetahuannya nelayan-nelayan tersebut telah mengetahui tentang adanya larangan dalam melakukan penangkapan kepada ikan terubuk tersebut dikarenakan adanya sosialisasi yang dilakukan oleh pihak-pihak terkait. ${ }^{18}$

Pada oktober 2019 pihak Pengawas Sumber Daya Kelautan dan Perikanan satwas rohil juga melakukan patroli terhadap penangkapan ikan terubuk dan di temukan 2 kapal yang diberikan surat peringatan tertulis serta diberikan sosialisasi berupa stiker dan brosur dikarenakan melakukan penangkapan terhadap ikan terubuk. Sedangkan pada tahun 2020 bulan oktober juga dilakukan patroli pada saat waktu larangan penangkapan ikan terubuk dan ditemukan 4 kapal yang diberikan surat peringatan tertulis pertama yang melakukan

\footnotetext{
17 Ibid

${ }^{18}$ Ibid
} 
penangkapan ikan terubuk, serta dilakukan sosialisasi berupa penempelan stiker dan juga pembagian brosur. Penempelan stiker dan pembagian brosur tidak hanya dilakukan terhadap kapal yang didalam nya terdapat ikan terubuk melainkan uga kepada setiap kapal yang ditemui pada saat dilakukan nya patroli tersebut. ${ }^{19}$

Kegiatan penegakan dan pelaksanaan perlindungan ikan terubuk dilakukan pengawasan oleh upt psdkp wilayah 2 dilakukan di waktu-waktu larangan. Sosialisasi Dinas Kelautan dan Perikanan Provinsi Riau dilakukan bekerjasama dengan Balai Pengelolaan Sumber Daya Pesisir dan Laut Padang Wilayah Kerja Pekanbaru dan Pengawas Sumber Daya Kelautan dan Perikanan satwas rohil dengan menyampaikan jenis-jenis ikan yang dilindungi di wilayah sungai pakning juli 2020 yang salah satu materinya mengenai ikan terubuk. Selain itu Dinas Kelautan dan Perikanan Provinsi Riau membentuk sebuah komunitas yang melibatkan peran masyarakat dalam pengawasan nya dengan membentuk dan membina Kelompok Masyarakat Pengawas di wilayah perlindungan ikan terubuk yang berjumlah 2 kelompok di daerah sungai pakning, 2 kelompok di wilayah bengkalis dan 1 kelompok di wilayah sungai apit. ${ }^{20}$

Terkait dengan alat tangkap dan tata cara masih ditemui nelayan yang menggunakan jaring batu di wilayah selat bengkalis yang mana bertentangan dengan ketentuan mengenai alat tangkap dan tata cara penangkapan. Jika dilihat dari sisi pengetahuan tentang larangan penangkapan ikan terubuk sesungguhnya nelayan yang terdapat di sekitar wilayah konservasi ikan terubuk sesungguhnya telah mengetahui tentang adanya peraturan dan larangan dalam waktu-waktu tertentu dalam hal penangkapan ikan terubuk, namun sampai saat ini nelayan tetap melakukan penangkapan ikan terubuk dengan modus penangkapan ikan biang yang secara tidak terduga turut terjaringnya ikan terubuk diwilayah selat bengkalis. ${ }^{21}$

Sampai saat ini masih belum ada proses penegakan hukum pidana dalam hal jika tertangkapnya nelayan yang masih melakukan penangkapan terhadap ikan terubuk dikarenakan nelayan-nelayan tersebut merupakan nelayan yang masuk kedalam kategori nelayan kecil dengan kapal di bawah 5 GT sehingga hanya diberikan surat teguran dan diarahkan untuk membuat pernyataan tidak akan mengulangi penangkapan ikan terubuk

\footnotetext{
${ }^{19}$ Ibid

${ }^{20}$ Wawancara dengan Bapak Dedek Dinas Kelautan dan Perikanan Provinsi Riau

${ }^{21}$ Ibid
} 
dikemudian hari serta dilakukan penyitaan alat tangkap jika menggunakan alat tangkap yang dilanggar. $^{22}$

\section{KESIMPULAN}

Proses perlindungan ikan terubuk dengan adanya Keputusan Menteri Kelautan dan Perikanan merupakan sebuah wujud dari kehadiran dan keseriusan pemerintah baik dalam hal ini pemerintah pusat maupun daerah dalam rangka untuk melindungi keberadaan dari ikan terubuk. Jika di tinjau dari aspek implementasi sanksi pidana dalam perlindungan terbatas jenis ikan terubuk di provinsi riau pada saat ini belum di laksanakan oleh jajaran terkait dikarenakan masih menggunakan pendekatan-pendekatan persuasif kepada nelayan yang masih melakukan penangkapan ikan terubuk dikarenakan nelayan-nelayan yang melakukan penangkapan ikan terubuk masih masuk dalam kategori nelayan kecil yang memiliki kapal yang tidak lebih dari 5 GT.

Proses pelaksanaan Keputusan Menteri Kelautan dan Perikanan di provinsi riau masih hanya berupa pemberian teguran baik secara lisan maupun tertulis disertai dengan dilakukannnya proses sosialisasi secara berkelanjutan dengan melakukan penempelan stiker kepada kapal-kapal nelayan dan pembagian brosur tentang pelarangan pnagkapan ikan terubuk pada tempat tertentu dan pada waktu tertentu. Diharapkan dari adanya proses pemberian teguran dan sosialisasi secara berkelanjutan dapat dicapainya tujuan dari Keputusan Menteri Kelautan dan Perikanan berupa perlindungan ikan terubuk.

\section{DAFTAR PUSTAKA}

\section{Buku}

Creswell, J. W., Research design: Qualitative and quantitative approaches, Thousand Oaks, CA: SAGE Publications. 1994.

M.Solly Lubis, Filsafat Ilmu dan Peneltian, Bandung :Mandar MAJU, 1994

Nunung Mahmudah, Illegal Fhising, , Jakarta: Sinar Grafika, 2015.

Soerjono Soekanto, Pengantar Penelitian Hukum, Jakarta: UI Press, 1986.

Jurnal

${ }^{22}$ Ibid 
Adi Tiaraputri dan Ledi Diana, Peran Serta Masyarakat Dalam Pengelolaan Sumber Daya Ikan di Kabupaten Bengkalis Dalam Perspektif Hukum Laut Nasional, Riau Law Journal 2, No. 1 (2018): 134.

\section{Peraturan Perundang-undangan}

Permen KKP Nomor PER.02/MEN/2009 tentang Tata Cara Penetapan Kawasan Konservasi Perairan.

\section{Website}

Kementerian Kelautan dan Perikanan, diakses 1 Maret 2021, https://kkp.go.id/djprl/bpsplpadang/page/316-terubuk. 